\title{
Genetics of Resistance to Ascochyta Blight in Four Chickpea Lines
}

\author{
K. B. Singh* and M. V. Reddy
}

\begin{abstract}
Inheritance of resistance to race 3 of Ascochyta blight (Ascochyta rabiei (Pass.) Lab.), an important disease in chickpea (Cicer arietinum L.), was studied in four resistant lines at ICARDA in Syria from 1983 to 1986 . The parents, $F_{1}$, and $F_{2}$ populations were evaluated for Ascochyta blight resistance under artificial epiphytotic conditions in the greenhouse during the 1983 to 1984 season. The $F_{3}$ progenies from selected $F_{2}$ resistant plants for each of the four crosses involving resistant and susceptible lines were evaluated for segregation of blight resistance and susceptibility in the greenhouse during the 1985 to 1986 season. Results suggested that a single dominant gene conditioned resistance to race 3 in the four parents, ILC 72, ILC 202, ILC 2956, and ILC 3279. Allelic tests indicated that the resistance gene present in these four resistant lines was the same. When these resistant parents were evaluated against six races of $A$. rabiei, each was resistant to races 1 and 3 and to at least two other races, but no two lines showed the same resistance pattern. Furthermore, the disease reaction of these resistant lines differed when tested in 13 countries. The variation in reaction of four resistant lines to six races and in different countries appears to be due to the presence of some other resistant genes in addition to a common gene.
\end{abstract}

A LTHOUGH ASCOCHYTA BLIGHT of chickpea has been reported from 26 countries (11), it is a major disease only in West Asia, North Africa, South and East Europe, Northern Pakistan, and Northwest India (15). In the rest of South Asia, which produces $50 \%$ of the chickpea production, Ascochyta blight is not a problem. Fungicides such as Chlorothalonil have been identified to control the disease, but their use seems impractical and uneconomical under epiphytotic conditions since a minimum of four to six sprays are required (13). The best way to control this disease is through the use of resistant cultivars (16).

The first resistant desi chickpea cultivar, namely $\mathrm{F}$ 8 , was released more than four decades ago in British India (9). This was followed by several releases, C 12$34 \mathrm{C}, \mathrm{C} 727, \mathrm{C} 235$, and CM $72(2,3,4,8)$. Most of these lines have succumbed to new races of $A$. rabiei. $\mathrm{Re}-$ cently, Cyprus, Spain, Syria, and Tunisia have selected eleven resistant kabuli chickpea lines from the ICARDA international nurseries and released them for commercial cultivation under the names of 'Yialousa', 'Kyrenia', 'Fardan', 'Zegri', 'Atalaya', 'Almena', 'Alcazaba', 'Ghab 1', 'Ghab 2', 'ILC 3279', and 'FLIP $83-46 C^{\prime}$ (6). So far, there is no report of breakdown of their resistances in the farmer's fields, but it is known already that Ghab 1 and Ghab 2 are resistant to certain races and susceptible to others (13).

Breeding for Ascochyta blight resistance is a major activity at ICARDA and in a few national programs.

K.B. Singh, Int. Ctr. for Agric. Res. in the Dry Areas (ICARDA) P.O. Box 5466, Aleppo, Syria; and M.V. Reddy, Int. Crops Res. Inst. for Semi-Arid Tropics (ICRISAT), Patancheru P.O., A.P. 502 324, India. Joint contribution from ICARDA and ICRISAT. Received 4 Jan. 1989. *Corresponding author.

Published in Crop Sci. 29:657-659 (1989).
To support these programs, knowledge about genetics of resistance is important. Previous studies showed that either one dominant gene or one recessive gene controlled the inheritance of resistance to Ascochyta blight $(1,5,7,15,17,18)$. Genetics of resistance to blight has been reported for 18 lines, but many more lines have been reported as resistant to this pathogen. Studies conducted at ICARDA (14) and national programs (11) have revealed the presence of numerous races. This necessitates breeding for specific races. The identification of races at ICARDA has helped direct the effort on resistance breeding. At ICARDA, four lines; namely, ILC 72, ILC 202, ILC 2956, and ILC 3279 are being used most extensively to transfer gene(s) for resistance to races $1,2,3$, and 4 of Ascochyta blight. In Syria the most common race of the fungus seems to be race 3 (14). Therefore, the present study was undertaken to determine the mode of inheritance of resistance in these four chickpea lines to race 3 of the A. rabiei pathogen.

\section{MATERIALS AND METHODS}

Four Ascochyta-resistant and one susceptible line to race 3 were selected from the ICARDA collection and crossed in a diallel (excluding reciprocals) in the field at Tel Hadya, ICARDA's principal experiment station in Syria during the 1982 to 1983 season. Of the four resistant lines, ILC 72 originated from Spain and the remaining three, ILC 202, ILC 2956, and ILC 3279 from the USSR. The susceptible line, ILC 35, was a local landrace from Syria. The $F_{1}$ plants from the ten crosses made at Tel Hadya were grown during the 1983 off-season at Terbol, Lebanon, to produce the $F_{2}$ seeds. The parents, $F_{1}$ and and $F_{2}$ populations of the ten crosses were grown in the greenhouse in plastic pots of 27.5 $\mathrm{cm}$ diam. at Tel Hadya during the 1983 to 1984 season. Fifteen plants of each parent and $F_{1}$ and between 100 and 200 plants of each $F_{2}$ were grown. Fifteen-day old plants were inoculated with a spore suspension $(40000$ spores $/ \mathrm{mL})$ prepared from a 15-d-old culture of race 3 of $A$. rabiei collected at Tel Hadya. The fungus was multiplied in a chickpea flour broth medium (13). Temperature was maintained around $20^{\circ} \mathrm{C}$ and plants were covered with a plastic cage of $60 \mathrm{~cm}$ height for $7 \mathrm{~d}$ to maintain a high relative humidity, favoring disease development. Inoculation was repeated when the plants were at podding stage. Disease severity was recorded after $30 \mathrm{~d}$ of second inoculation on a 1 to 9 scale and plants rated 1 to 5 were considered resistant whereas those rated 6 to 9 were considered susceptible (15).

Twenty resistant $F_{2}$ plants were selected from each of the four crosses involving resistant $X$ the susceptible parent and $\mathrm{F}_{3}$ seeds were collected. Twenty plants of each of the $20 \mathrm{~F}_{3}$ progenies from each of the four crosses were grown in the greenhouse in plastic pots during the 1985 to 1986 season. These plants were grown in four pots, five plants per pot. The $F_{3}$ material was handled the same way as that of $F_{2}$ populations for inoculation and disease development. Disease severity was recorded on a progeny basis.

The five parents were also evaluated against six races of the fungus in the greenhouse during the 1985 to 1986 season following the methods described by Reddy and Kabbabeh (14). These six races were obtained from Syria and Lebanon. 
Table 1. Reaction of $F_{2}$ populations of chickpea derived from crosses of resistant $X$ resistant and resistant $\times$ susceptible lines to race 3 of Aschochyta rabiei in greenhouse testing at Tel Hadya, Syria in the 1983 to 1984 season.

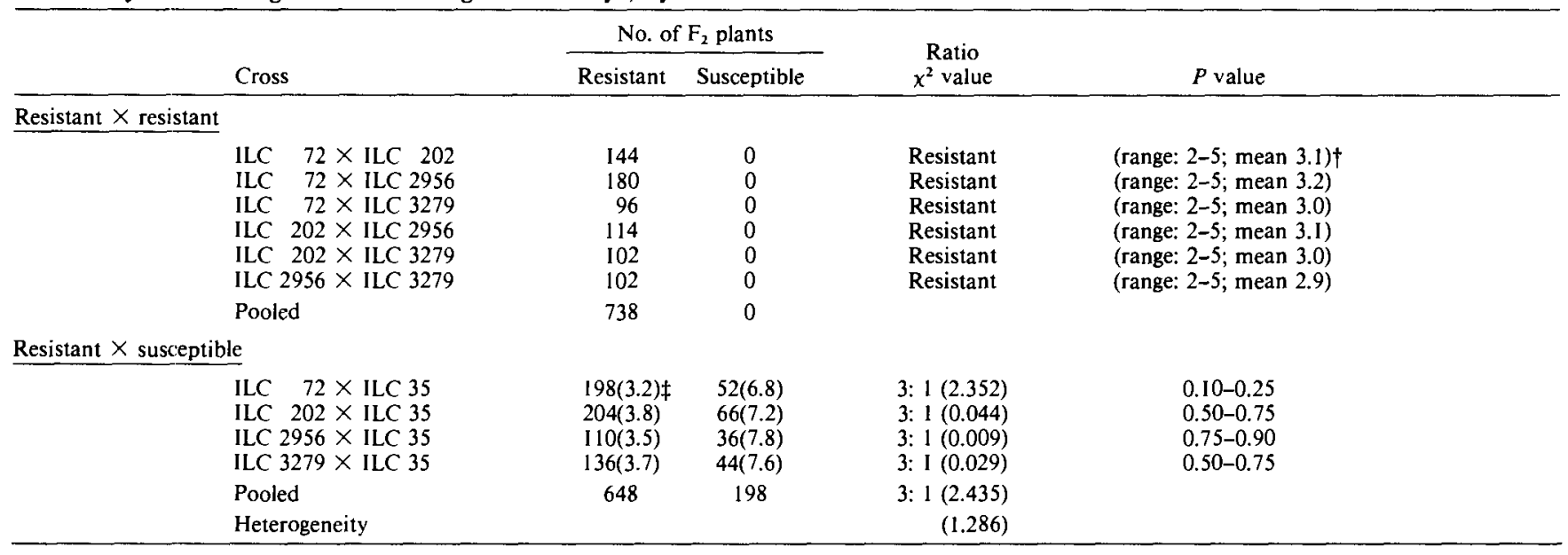

$\dagger$ Scores for individual plants varied from 2 to 5 on a $1-9$ scale.

$\ddagger$ Mean score of all plants.

Four Ascochyta-resistant parents were evaluated internationally along with other resistant lines through the Chickpea International Ascochyta Blight Nursery (CIABN). Results of these tests have also been included in this study.

\section{RESULTS AND DISCUSSION}

All plants of ILC 72, ILC 202, ILC 2956, and ILC 3279 were resistant, whereas those of ILC 35 were susceptible to race 3 of $A$. rabiei in the greenhouse tests during the 1983 to 1984 season. All the $F_{1}$ plants of the six crosses involving resistant $X$ resistant parents showed a resistant reaction. Ratings of individual plants in $F_{2}$ populations were generally between 2 and 4 and occasionally 5 on a 1 to 9 scale. Mean ratings of all plants in six crosses ranged from 2.9 to 3.2 (Table 1). This range in rating was also observed in the parents. Therefore, all $F_{2}$ plants of these resistant $X$ resistant crosses were judged to be resistant and segregation was not observed in the populations of these crosses. This indicated similar, or identical genes/alleles for resistance to race 3 in these parents (Table 1).

The $F_{1}$ plants of the four crosses involving resistant $X$ susceptible parents were resistant, indicating that resistance is dominant. The $F_{2}$ segregation ratio gave a good fit to 3 resistant: 1 susceptible, as expected for a single dominant gene for resistance (Table 1). The $F_{3}$ families grown from the individual resistant $F_{2}$ plants gave a good fit to the expected ratio of 1 resis-

Table 2. Reaction of plants in $F_{3}$ families grown from resistant $F_{2}$ plants to race 3 of Ascochyta rabiei in the greenhouse at Tel Hadya, Syria, 1985-1986.

\begin{tabular}{|c|c|c|c|c|}
\hline \multirow[b]{2}{*}{ Cross } & \multicolumn{2}{|c|}{ No. of families } & \multirow[b]{2}{*}{$\begin{array}{c}\text { Ratio } 1: 2 \\
\chi^{2} \text { value }\end{array}$} & \multirow[b]{2}{*}{$P$ value } \\
\hline & $\begin{array}{l}\text { True breeding } \\
\text { for resistance }\end{array}$ & Segregating & & \\
\hline $\begin{array}{lr}\text { ILC } & 72 \times \text { ILC } 35 \\
\text { ILC } & 202 \times \text { ILC } 35 \\
\text { ILC } 2956 \times \text { ILC } 35 \\
\text { ILC } 3279 \times \text { ILC } 35\end{array}$ & $\begin{array}{l}6 \\
5 \\
7 \\
8\end{array}$ & $\begin{array}{l}14 \\
15 \\
13 \\
12\end{array}$ & $\begin{array}{l}0.017 \\
0.625 \\
0.024 \\
0.398\end{array}$ & $\begin{array}{l}0.50-0.75 \\
0.25-0.50 \\
0.50-0.75 \\
0.50-0.75\end{array}$ \\
\hline Pooled & 26 & 54 & 1.150 & $0.25-0.50$ \\
\hline Heterogeneity & & & 1.125 & \\
\hline
\end{tabular}

tant: 2 segregating progenies, confirming the single dominant gene in the four resistant parents (Table 2). The present study, therefore, indicated that resistance to race 3 of $A$. rabiei in chickpea is due to a single dominant gene in ILC 72, ILC 202, ILC 2956, and ILC 3279. The test of allelism among the resistant lines suggested that the dominant alleles for resistance were the same.

The five parents included in this study were also evaluated in the greenhouse against the six races of $A$. rabiei identified in Syria and Lebanon by Reddy and Kabbabeh (14). All four resistant parents were resistant to races 1 and 3 and at least two other of the six races tested (Table 3). But no two of the four resistant parents had a similar reaction to all six races tested, indicating they differ in resistance gene(s) or allele(s) to other races. The susceptible line ILC 35 was susceptible to all the races.

Additionally, these resistant lines have been tested internationally through the Chickpea International Ascochyta Blight Nursery (CIABN) since 1978 to 1979 and they varied in reaction among different countries (Table 4). Results indicated that different races of the pathogen are involved in various countries. Alternatively, the four host genotypes may possess different minor genes in addition to the common major resistant gene against race 3, thereby affecting their disease rating. The differential reactions observed among the four genotypes against four out of six races in the present study lend credence to the hypothesis that different races are involved in various countries.

Table 3. Reaction of the chickpea parents used in the inheritance study to six races of Ascochyta rabiei in the greenhouse at Tel Hadya, Syria, 1985-1986.

\begin{tabular}{lllllll}
\hline \multirow{2}{*}{$\begin{array}{l}\text { Parental } \\
\text { line }\end{array}$} & $\mathrm{I}$ & 2 & 3 & 4 & 5 & 6 \\
\hline ILC 72 & $\mathrm{R}$ & $\mathrm{R}$ & $\mathrm{R}$ & $\mathrm{R}$ & $\mathrm{S}$ & $\mathrm{S}$ \\
ILC 202 & $\mathrm{R}$ & $\mathrm{R}$ & $\mathrm{R}$ & $\mathrm{R}$ & $\mathrm{R}$ & $\mathrm{S}$ \\
ILC 2956 & $\mathrm{R}$ & $\mathrm{S}$ & $\mathrm{R}$ & $\mathrm{S}$ & $\mathrm{R}$ & $\mathrm{R}$ \\
ILC 3279 & $\mathrm{R}$ & $\mathrm{S}$ & $\mathrm{R}$ & $\mathrm{R}$ & $\mathrm{R}$ & $\mathrm{S}$ \\
ILC 35 & $\mathrm{S}$ & $\mathrm{S}$ & $\mathrm{S}$ & $\mathrm{S}$ & $\mathrm{S}$ & $\mathrm{S}$ \\
\hline
\end{tabular}

$\dagger \mathrm{R}=$ resistant; $\mathrm{S}=$ susceptible 
Table 4. Reaction of the four chickpea resistant parents to Ascochyta rabiei in different countries when tested in the CIABN during different seasons from 1978-1979 to $1984-1985 \dagger$.

\begin{tabular}{|c|c|c|c|c|c|c|c|c|c|c|c|c|}
\hline Lines & Algeria & Greece & India & Italy & Jordan & Morocco & Pakistan & Spain & Syria & Tunisia & Turkey & USA \\
\hline ILC 72 & NT‡ & $\mathbf{R}$ & $\mathbf{s}$ & $\mathbf{R}$ & $\mathbf{R}$ & $\mathbf{R}$ & $\mathrm{R}, \mathrm{S}$ & $\mathbf{R}$ & $\mathbf{R}$ & $\mathbf{s}$ & $\mathrm{R}, \mathrm{S}$ & $\mathbf{R}$ \\
\hline ILC 202 & $R$ & $\mathrm{R}$ & S & $\mathrm{R}$ & S & $\mathrm{R}$ & $\mathrm{R}, \mathrm{S}$ & $\mathbf{R}$ & $\mathbf{R}$ & S & $\mathrm{R}, \mathbf{S}$ & $\mathbf{R}$ \\
\hline ILC 2956 & NT & $\mathbf{R}$ & S & $\mathrm{R}$ & $\mathbf{R}$ & $\mathbf{R}$ & $\mathrm{R}, \mathrm{S}$ & NT & $\mathbf{R}$ & S & $\mathbf{R}, \mathbf{S}$ & $\mathbf{R}$ \\
\hline ILC 3279 & $\mathrm{R}$ & $\mathrm{R}$ & S & $\mathrm{R}$ & $\mathrm{R}$ & S & $\mathbf{R}, \mathbf{S}$ & $\mathbf{R}$ & $\mathrm{R}$ & $\mathbf{R}$ & $\mathrm{R}, \mathrm{S}$ & $\mathbf{R}$ \\
\hline
\end{tabular}

$\dagger$ Not all lines were evaluated every year and the reaction was not necessarily consistent at all locations within a country.

$\ddagger R=$ Resistant. $S=$ susceptible, $N T=$ not tested, $R, S=$ these reactions occurred in different locations within country.

All previous studies $(1,5,7,12,15,17,18)$ were made against a single race and reported a single dominant or recessive gene conferring resistance to $A$. rabiei. The present study was also made against a single race, and only one dominant gene was found to control resistance to the Ascochyta pathogen. But, evaluation of four resistant lines against six races in the greenhouse at Tel Hadya and internationally through CIABN indicated that four parents may have other genes for resistance in addition to a common resistant gene against race 3 . Presence of different races in different countries indicates that breeding for race-specific resistance has to be taken up by national programs.

There is a need to assemble and study the inheritance of the resistance genes reported previously and in this paper to a common set of races of the pathogen. This type of study would help in identification of different genes conferring resistance to the various races of the Ascochyta pathogen. Attempts then should be made to develop cultivars with more durable resistance by pyramiding resistance genes. The use of gene pyramiding with many resistance genes in a single genetic background might confer a long-lived horizontal resistance, which would be very difficult to overcome because of the requirement of many mutations in the pathogen at the same time (10). Such an effort is being made by ICARDA and cooperation at the national level is being sought.

\section{ACKNOWLEDGMENTS}

We wish to thank most sincerely Mrs. S. Kabbabeh and Mr. Gaby Khalaf for their assistance in carrying out the study. Authors are grateful to cooperators in national programs for testing and providing data of the CIABN.

\section{REFERENCES}

1. Acikgoz, N. 1983. An investigation on the sources of resistance and inheritance of resistance to Ascochyta blight in chickpea. (In Turkish.) Ege Bolge Zirai Arastirma Enstitusu Yaginlari no. 29.

2. Ahmed, T.S., N. Hasanain, and A. Sattar. 1949. Some popular methods of plant disease control in Pakistan. Agric. Pak. 1:1822 .

3. Aziz, A.M. 1962. C 727-A new blight resistant gram variety for Barani areas. West. Pak. J. Agric. Res. 1:165-166.

4. Bedi, K.S. and D.S. Athwal. 1962. C 235 is the answer to blight. Indian Farming 12:20-22.

5. Eser, D. 1979. Heritability of some important plant characters, their relationships with plant yield and inheritance of Ascochyta blight resistance in chickpea (Cicer arietinum L.). (In Turkish.) Ankara Universitiesi Ziraat Fakultesi Yayinlari 620.

6. Food Legume Improvement Program (FLIP). 1986. Annual report for 1986. ICARDA, P.O. Box 5466, Aleppo, Syria.

7. Hafiz, A., and M. Asraf. 1953. Studies on the inheritance of resistance to Mycosphaerella blight in gram. Phytopathology 43:580-581.

8. Haq, M.A., M. Siddique, and M. Hassan. 1984. Introduction of Ascochyta blight resistance in chickpea through induced mutations. 4th FAO-IAEA res. coordination meeting on the use of Induced Mutations for improvement of Grain Legume Production. Nuclear inst. of Agric. and Biology, Faisalabad, Pakistan. 3-7 Mar. 1984.

9. Luthra, J.C., A. Sattar, and K.S. Bedi. 1941. Determination of resistance to blight disease, Mycosphaerella rabiei Kovaceveski - Ascochyta rabiei (Pass.) Lab. in gram types. Indian J. Agric. Sci. 11:249-264.

10. Nelson, R.R. 1973. The use of resistance genes to curb population shifts in plant pathogens. p. 49-66. In R.R. Nelson (ed.) Breeding plants for disease resistance: Concepts and applications. The Pennsylvania State Univ. Press, University Park.

11. Nene, Y.L. 1984. A review of ascochyta blight of chickpea ( $\mathrm{C} i$ cer arietinum L.). p. 17-34. In M.C. Saxena and K.B. Singh (ed.) Ascochyta blight and winter sowing of chickpeas. Martinus Nijhoff-Dr. W. Junk Publ., the Hague, Netherlands.

12. Reddy, M.V., and Y.L. Nene. 1978. Screening of Cicer spp. for resistance to Ascochyta blight. p. 305. In Proc. 3rd Int. Congress of Plant Pathology, Munich, West Germany. 23-28 Aug. 1978.

13. --, and K.B. Singh. 1983. Foliar application of Bravo 500 for Ascochyta blight control. Int. Chickpea Newsl. 8:25-26.

14. ---, and S. Kabbabeh. 1985. Pathogenic variability in $A s-$ cochyta rabiei (Pass.) Lab. in Syria and Lebanon. Phytopath. medit. 24:265-266.

15. Singh, K.B., and M.V. Reddy. 1983. Inheritance of resistance to Ascochyta blight in chickpea. Crop Sci. 23:9-10.

16. ---, H.E. Gridely, and G.C. Hawtin. 1984. Strategy for breeding Ascochyta blight resistant cultivars. p. 95-1 10. In M.C. Saxena and K.B. Singhs (ed.) Ascochyta blight and winter sowing of chickpeas. Martinus Nijhoff-Dr. W. Junk Publ., The Hague, Netherlands.

17. Tewari, S.K., and M.P. Pandey. 1986. Genetics of resistance to Ascochyta blight in chickpea (Cicer arietinum L.). Euphytica 35:211-215.

18. Vir, S., J.S. Grewal, and V.P. Gupta. 1975. Inheritance of resistance to Ascochyta blight in chickpea. Euphytica 24:209-211. 